\title{
ANALISIS KONSENTRASI CO (KARBON MONOKSIDA) UDARA AMBIEN DARI SUMBER KENDARAAN BERMOTOR DENGAN MENGGUNAKAN MODEL METI-LIS DI KAWASAN BALAI KOTA, MEDAN
}

\author{
Isra’ Suryati ${ }^{1)^{*}}$, Juni Hasudungan Siburian ${ }^{2)}$, Ahmad Rezky Daulay ${ }^{3)}$, Ivan Indrawan ${ }^{4)}$ \\ 1,2,3 Program Studi Teknik Lingkungan, Fakultas Teknik, Universitas Sumatera Utara, Jl. Almamater Kampus \\ USU, Medan 20155, Indonesia \\ ${ }^{4}$ Departemen Teknik Sipil, Fakultas Teknik, Universitas Sumatera Utara, Jl. Almamater Kampus USU, Medan \\ 20155, Indonesia \\ israt1@usu.ac.id*; junihasudungan@gmail.com; ekydaulay18@gmail.com; ivan.indrawan@usu.ac.id
}

\begin{abstract}
ABSTRAK
Pemodelan dispersi polutan dapat membantu memprediksi distribusi polutan dari berbagai sumber emisi. Hasil pemodelan dispersi polutan dapat digunakan sebagai dasar untuk menentukan pengelolaan kualitas udara. Lokasi dari penelitian ini berada di kawasan Balai Kota Medan yang menjadi salah satu fokus lalu lintas teraktif di Kota Medan. Tujuan dibalik tinjauan ini adalah untuk memperkirakan sebaran CO dari sumber kendaraan di kawasan Balai Kota, memetakan sebaran $\mathrm{CO}$, dan membandingkan hasil model dan pengamatan langsung di lapangan. Model dispersi polutan yang digunakan pada penelitian ini yaitu Model Meti-Lis. Berdasarkan pengamatan volume lalu lintas di 6 titik pengamatan, titik 2 merupakan lokasi dengan jumlah kendaraan terbanyak yaitu 9.532 unit/jam (hari) dengan laju emisi 130,49 $\mathrm{g} / \mathrm{m} / \mathrm{jam}$. Berdasarkan hasil model Meti-Lis, konsentrasi CO tertinggi juga ditemukan pada titik 2 sebesar $2.452 \mathrm{~g} / \mathrm{Nm} 3$. Hasil pengukuran langsung di lapangan diperoleh konsentrasi maksimum sebesar 8.952,38 g/Nm3 pada titik 2. Uji validasi dengan indeks Wilmott menghasilkan $\mathrm{d}=0,998$, $\mathrm{R}=0,917$, $\mathrm{FB}=-0,085$, dan $\mathrm{Fa} 2=0,133$. Hasil validasi menunjukkan bahwa Model Meti-Lis dapat direkomendasikan dalam pemodelan dispersi polutan di sekitar kawasan Balai Kota Medan.
\end{abstract}

Kata kunci: CO, Model Dispersi, Meti-Lis, Pengelolaan Kualitas Udara.

\section{ABSTRACT}

Pollutant dispersion modeling can help predict the distribution of pollutants from various emission sources. The results of pollutant dispersion modeling can be used as a basis for determining air quality management. The location of this research is in the Medan City Hall area which is one of the most active traffic focuses on Medan City. The purpose of all this is a vehicle for assessing the distribution of $\mathrm{CO}$ from sources in the City Hall area, comparing CO results, and comparing models and directly in the field. The pollutant dispersion model used in this study is the Meti-Lis Model. Based on the traffic volume at 6 observation points, point 2 is the location with the highest number of vehicles, namely 9,532 units/hour (day) with an emission rate of $130.49 \mathrm{~g} / \mathrm{m} / \mathrm{hour}$. Based on the results of the Meti-Lis model, the highest $\mathrm{CO}$ concentration was also found at point 2 at $2,452 \mathrm{~g} / \mathrm{Nm} 3$. The results of direct measurements in the field obtained a maximum concentration of $8,952.38 \mathrm{~g} / \mathrm{Nm} 3$ at point 2 . Validation test with the Wilmott index resulted in $\mathrm{d}=0.998, \mathrm{R}=0.917, \mathrm{FB}=-0.085$, and $\mathrm{Fa} 2=0.133$. The validation results show that the Meti-Lis Model can be recommended in modeling the distribution of pollutants around the Medan City Hall area.

Keywords: CO, Dispersion Model, Meti-Lis, Air Quality Management. 
Copyright (c) 2021 Isra' Suryati, Juni Hasudungan Siburian, Ahmad Rezky Daulay, Ivan Indrawan This is an open access article under the CC-BY license

\section{PENDAHULUAN}

Kota Medan sebagai ibu kota dari Provinsi Sumatera Utara mempunyai jumlah penduduk sebesar \pm 2.264 .145 jiwa pada tahun 2018 dan mengalami peningkatan $0,74 \%$ setiap tahunnya (Badan Pusat Statistik Kota Medan 2019). Peningkatan jumlah penduduk tersebut juga diiringi dengan meningkatnya penggunaan kendaraan bermotor yang berkontribusi besar dalam menyumbang polusi udara di Kota Medan. Bertambahnya jumlah penduduk juga meningkatkan penggunaan kendaraan bermotor serta aktivitas perkotaan lainnya seperti kegiatan industri yang dapat menimbulkan pencemaran pada udara. Pencemaran udara pada umumnya berasal dari transportasi, kegiatan industri, pembakaran sampah, dan pembakaran hutan.

Udara merupakan kebutuhan paling dasar bagi kehidupan makhluk hidup, sehingga perlu adanya tindakan perlindungan terhadap kualitas udara dari bahan pencemar yang bersifat beracun. Menurut (Indonesia 2021) PPRI No.22 Tahun 2021 tentang Penyelenggaraan Perlindungan dan Pengelolaan Lingkungan (Pasal 1 Ayat 49), pencemaran udara adalah masuk atau dimasukkannya zat, energi, dan/atau komponen lainnya ke dalam udara ambien oleh kegiatan manusia sehingga melampaui baku mutu udara ambien yang telah ditetapkan.

Jenis polutan primer yang diemisikan dari kendaraan adalah karbon monoksida (CO) dan berdampak buruk pada kesehatan. CO yang terhirup dalam kadar rendah dapat menyebabkan gangguan pernapasan, detak jantung, refleksi saraf, dan ketegangan peredaran darah, sedangkan pada kadar yang lebih tinggi dapat mengakibatkan kematian pada manusia (Aslim, Ihsan, and Yani 2019). CO dapat mengikat hemoglobin (Hb) untuk membentuk karboksihemoglobin $(\mathrm{COHb})$ di dalam darah, dimana afinitas terhadap $\mathrm{COHb}$ tersebut lebih besar dibandingkan dengan $\mathrm{O} 2 \mathrm{Hb}$ (Oxyhemoglobin) yang dapat menyebabkan gas $\mathrm{CO}$ sulit lepas dari $\mathrm{Hb}$, sehingga mengakibatkan turunnya kapasitas $\mathrm{Hb}$ sebagai pengangkut oksigen dalam darah (Aslim, Ihsan, and Yani 2019).

Menurut (Suryati 2016), dari pengambilan CO udara ambien yang difokuskan pada 12 (dua belas) titik yang telah ditentukan dengan waktu penentuan pagi dan sore hari, dimana nilai fiksasi $\mathrm{CO}$ yang paling tinggi bersumber dari transportasi berada di beberapa jalan di Kota Medan yang tergolong sibuk, diantaranya, Jl. Gatot Subroto, Jl. SM Raja, Jl. Pusat kota, dan Jl. MT Haryono. Konsentrasi CO keluar yang tinggi akan berdampak buruk bagi pengguna jalan, pejalan kaki, pengendara sepeda motor, polisi lalu lintas, pedagang di sekitar jalan, dan reseptor berbeda lainnya.

Tabel 1. Beban Emisi CO di Beberapa Ruas Jalan Kota Medan

\begin{tabular}{cccc}
\hline No & Nama Jalan & $\begin{array}{c}\text { Waktu } \\
\text { Pengukuran }\end{array}$ & Beban Emisi (g/jam) \\
\hline \multirow{2}{*}{1.} & \multirow{2}{*}{ Jalan Gatot Subroto } & Pagi & $22.552,12$ \\
& & Siang & $17.048,54$ \\
& & Sore & $32.557,92$ \\
\hline \multirow{2}{*}{2.} & \multirow{2}{*}{ Jalan Balai Kota } & Pagi & $23.907,12$ \\
& & Siang & $50.293,14$ \\
& & Sore & $92.044,14$ \\
\hline \multirow{2}{*}{3.} & \multirow{2}{*}{ Jalan Sisingamangaraja } & Pagi & $25.420,08$ \\
& & Siang & $21.201,54$ \\
& & Sore & $27.454,92$ \\
\hline
\end{tabular}

(Sumber; (Ilmiawan 2019))

Berdasarkan penelitian yang dilakukan (Ilmiawan 2019), beban emisi CO tertinggi pada pagi hari adalah di jalan Sisingamangaraja. Sementara itu, pada siang dan sore hari, nilai beban 
emisi tertinggi berada di Jalan Balai Kota. Dengan demikian, perlunya dilakukan penelitian lebih lanjut terkait sebaran konsentrasi CO ambien di sekitar Kawasan Balai Kota, Medan.

Menurut data ISPU (Indeks Standard Pencemaran Udara), data yang ditunjukkan oleh stasiun pemantauan kualitas udara ambien yang berlokasi di lapangan merdeka (Kawasan Balai Kota) diperoleh indeks kualitas udara untuk parameter $\mathrm{CO}$ berada pada kisaran angka 119 sampai 185, dimana pada kategori ini termasuk dalam kategori "Tidak Sehat" (100-199= Kategori Tidak Sehat). Sejalan dengan itu, sangat penting untuk dilakukannya penelitian lebih lanjut tentang penyebaran konsentrasi CO ambien di sekitar Kawasan Balai Kota, Medan.

Pengendalian pencemaran udara dapat dilakukan dengan mengetahui terlebih dahulu dispersi polutan dengan simulasi menggunakan suatu pemodelan. Jenis pemodelan disperse polutan ada beberapa macam yaitu Gaussian Model, Box Model, Lagranginam Model, Computational Fluid Dynamics (CFD) Model, dan Eulerian Model (Vega Paramitadevi 2014).

Berdasarkan hasil penelitian (Vega Paramitadevi 2014), Gaussian Model terbagi menjadi 4 yaitu: Delhi Finite Line Source (DLLS), Gaussian Point Source, Gaussian Line Source, Finite Length Source (FLLS). Gaussian line source adalah salah satu metode yang sering digunakan karena di anggap paling tepat dalam menggambarkan penyebaran pencemaran udara.

Pemodelan untuk sumber garis (line source) yang digunakan dalam penelitian ini adalah Meti-Lis yang dasar pemodelannya adalah Gaussian. Program Meti-Lis dapat memprediksi sebaran polutan CO di sekitar jalan. Adapun parameter input utama yang dimiliki Program Meti-Lis yaitu, operation pattern, objective substance, map, meteorology, line source, point source, receptor, building, dan calculation case. Kelebihan dari model Meti-Lis yaitu dapat memprakirakan sebaran polutan dan besarnya dampak terhadap lingkungan di sekitar lokasi pengamatan.

\section{METODE}

\section{Lokasi dan Waktu Penelitian}

Lokasi pengamatan jumlah dan jenis kendaraan dilakukan di kawasan Balai Kota Medan. Lokasi pengukuran $\mathrm{CO}$ secara langsung dilakukan di 6 titik reseptor yang telah ditentukan. Pengukuran dilakukan pada jarak 1 sampai 5 meter dari pinggir jalan raya dengan lokasi dan titik koordinat pada Tabel 2.

Tabel 2. Koordinat Titik Sampling CO di Lapangan

\begin{tabular}{|c|c|c|c|}
\hline $\begin{array}{ll}\text { Nomor } & \text { Titik } \\
\text { Sampling } & \\
\end{array}$ & $\begin{array}{ll}\text { Lokasi } & \text { Titik } \\
\text { Pengamatan } & \\
\end{array}$ & Lintang Utara (LU) & Bujur Timur (BT) \\
\hline 1. & Bank Muamalat & $3^{\circ} 35^{\prime} 22.45^{\prime \prime} \mathrm{N}$ & $98^{\circ} 40^{\prime} 40.06^{\prime \prime} \mathrm{E}$ \\
\hline 2. & Grand Inna & $3^{\circ} 35^{\prime} 29.18^{\prime \prime} \mathrm{N}$ & $98^{\circ} 40^{\prime} 37.37^{\prime \prime E}$ \\
\hline 3. & Deli Park & $3^{\circ} 35^{\prime} 41.11^{\prime \prime} \mathrm{N}$ & $98^{\circ} 40^{\prime} 33.20^{\prime \prime} \mathrm{E}$ \\
\hline 4. & Grapari Telkomsel & $3^{\circ} 35^{\prime} 29.44^{\prime \prime} \mathrm{N}$ & $98^{\circ} 40^{\prime} 37.41 " \mathrm{E}$ \\
\hline 5. & Mini Market YES 248 & $3^{\circ} 35^{\prime} 30.38^{\prime \prime} \mathrm{N}$ & $98^{\circ} 40^{\prime} 42.94^{\prime \prime} \mathrm{E}$ \\
\hline 6. & Bank Mandiri & $3^{\circ} 35^{\prime} 21.08^{\prime \prime} \mathrm{N}$ & $98^{\circ} 40^{\prime} 45.23^{\prime \prime} \mathrm{E}$ \\
\hline
\end{tabular}

(Sumber : Survei dan analisa, 2020)

\section{Pengumpulan Data}

Data yang diperlukan dalam peneltian ini adalah data primer dan data sekunder. Pengumpulan data primer yaitu menghitung volume kendaraan (jumlah dan jenis kendaraan) dengan traffic counting, temperatur, koordinat jalan dan reseptor, serta konsentrasi $\mathrm{CO}$ yang diukur menggunakan alat automatic sampler. Adapun data sekunder yang dikumpulkan adalah kecepatan dan arah angin, data konsentrasi CO penelitian terdahulu sebagai dasar penentuan titik sampling, peta Kawasan Balai Kota, dan data ISPU di Kawasan Balai Kota Medan. 


\section{Analisis Data}

Langkah awal yaitu melakukan perhitungan laju emisi $\mathrm{CO}$ dari data traffic counting dengan menggunakan rummus sebagai berikut:

$$
\mathrm{Q}=\left(\sum_{\mathrm{i}=1}^{\mathrm{n}} \mathrm{EF}_{\mathrm{i}} \mathrm{xV}\right) \mathrm{x}\left(\frac{1}{\mathrm{~T}}\right)
$$

keterangan:

Q : Laju emisi (g/km)

EFi : Faktor emisi setiap kendaraan (gram/km)

$\mathrm{V} \quad$ : Volume kendaraan (Kendaraan/jam)

i : Jenis kendaraan

T : Waktu

Nilai faktor emisi kendaraan bermotor dapat dilihat pada tabel 3.

Tabel 3. Faktor Emisi Kendaraan Bermotor di Indonesia

\begin{tabular}{ll}
\hline Jenis Kendaraan & Faktor Emisi CO $(\mathbf{g} / \mathbf{k m})$ \\
\hline Sepeda Motor & 14 \\
\hline Mobil Penumpang (bensin) & 40 \\
\hline Mobil Penumpang (solar) & 2,8 \\
\hline Mobil Penumpang & 32,4 \\
\hline Bis & 11 \\
\hline Truk & 8,4 \\
\hline (Sumber : (Kementrian Lingkungan Hidup 2010))
\end{tabular}

Nilai laju emisi akan digunakan untuk input data pada program Model Meti-Lis. Adapun data lainnya yang diperlukan dalam input data Model Meti-Lis yaitu arah dan kecepatan angim,temperature, serta lebar jalan dan lokasi reseptor.

Selanjutnya, Uji validasi dilakukan untuk melihat kesesuaian hasil konsentrsi dari pengukuran langsung dilapangan dan hasil dari Model Meti-Lis. Validasi yang digunakan terdiri dari Korelasi Pearson (R), Wilmott's Index of Agreement (d), Factor of 2 (Fa2 ᄀ),dan Friction Bias (FB).

$\mathrm{d}=1-\frac{\overline{\left(\mathrm{C}_{\text {pred }}-\mathrm{C}_{\text {obs }}\right)^{2}}}{\overline{\left(\left|\mathrm{C}_{\text {pred }}-\overline{\mathrm{C}_{\text {obs }}}\right|+\mid \mathrm{C}_{\text {obs }}-\overline{\mathrm{C}_{\text {obs }}}\right)^{2}}}$

$\mathrm{R}=\frac{\overline{\left(\mathrm{C}_{\text {obs }}-\mathrm{C}_{\text {obs }}\right)\left(\mathrm{C}_{\text {pred }}-\overline{\mathrm{C}_{\text {pred }}}\right)}}{\sigma_{\text {obs }} \sigma_{\text {pred }}}$

$\mathrm{FB}=\frac{2\left(\overline{\mathrm{C}_{\text {pred }}}-\overline{\mathrm{C}_{\mathrm{obs}}}\right)}{\mathrm{C}_{\text {pred }}+\mathrm{C}_{\text {obs }}}$

$\mathrm{Fa}_{2}$ adalah fraksi data, dengan rumus sebagai berikut:

$0,5<\frac{\mathrm{C}_{\text {pred }}}{\mathrm{C}_{\text {obs }}}<2$

Keterangan:

Cpred $\quad$ : Konsentrasi CO model $(\mu \mathrm{g} / \mathrm{Nm} 3)$

Cobs $\quad$ : Konsentrasi CO di lapangan $(\mu \mathrm{g} / \mathrm{Nm} 3)$

$(\text { C_pred })^{-} \quad$ : Rerata konsentrasi CO model $(\mu \mathrm{g} / \mathrm{Nm} 3)$

$\left(C_{-} \text {OBS }\right)^{-} \quad$ : Rerata konsentrasi CO di lapangan $(\mu \mathrm{g} / \mathrm{Nm} 3)$

$\sigma \quad$ : Standar deviasi konsentrasi CO model

$\sigma \_$pred $\quad:$ Standar deviasi konsentrasi CO di lapangan.

Nilai validasi yang baik berdasarkan kriteria berikut (Kumar et al., 2003 dalam Paramitadevi, 2014):

1. FB (-2 sampai dengan 2)

2. Nilai $R$ (mendekati 1)

3. Nilai d (mendekati 1) 
4. Fa2 (sekitar 50\%).

\section{HASIL DAN PEMBAHASAN \\ Volume Lalu Lintas}

Hasil traffic counting pada saat pengukuran konsentrasi CO langsung di lapangan disajikan pada Tabel 4.

Tabel 4. Hasil Traffic Counting di Sekitar Kawasan Balai Kota

\begin{tabular}{|c|c|c|c|c|c|c|}
\hline No & $\begin{array}{l}\text { Nama } \\
\text { Lokasi }\end{array}$ & Waktu & $\begin{array}{l}\text { Sepeda } \\
\text { Motor }\end{array}$ & Mobil & Bus & Truk \\
\hline \multirow{3}{*}{1.} & \multirow{3}{*}{$\begin{array}{l}\text { Bank } \\
\text { Muamalat }\end{array}$} & Pagi & 2842 & 1035 & 5 & 11 \\
\hline & & siang & 1922 & 1411 & 11 & 26 \\
\hline & & sore & 2298 & 1595 & 4 & 22 \\
\hline \multirow{3}{*}{2.} & \multirow{3}{*}{$\begin{array}{l}\text { Hotel } \\
\text { Grand } \\
\text { Inna }\end{array}$} & pagi & 6539 & 2701 & 15 & 59 \\
\hline & & siang & 3514 & 2990 & 2 & 44 \\
\hline & & sore & 6142 & 3334 & 9 & 47 \\
\hline \multirow{3}{*}{3.} & \multirow{3}{*}{$\begin{array}{l}\text { Grapari } \\
\text { Telkomsel }\end{array}$} & pagi & 3066 & 1754 & 8 & 18 \\
\hline & & siang & 1905 & 1552 & 8 & 28 \\
\hline & & sore & 2547 & 1685 & 3 & 25 \\
\hline \multirow{3}{*}{4.} & \multirow{3}{*}{ Deli Park } & pagi & 2822 & 2015 & 4 & 15 \\
\hline & & siang & 2317 & 1735 & 2 & 30 \\
\hline & & sore & 3954 & 2052 & 9 & 21 \\
\hline \multirow{3}{*}{5.} & \multirow{3}{*}{$\begin{array}{l}\text { Mini } \\
\text { YES } 248\end{array}$} & pagi & 1270 & 736 & 2 & 4 \\
\hline & & siang & 1087 & 815 & 5 & 15 \\
\hline & & sore & 1194 & 625 & 2 & 8 \\
\hline \multirow{3}{*}{6.} & \multirow{3}{*}{$\begin{array}{l}\text { Bank } \\
\text { Mandiri }\end{array}$} & pagi & 1936 & 153 & 1 & 7 \\
\hline & & siang & 1193 & 1142 & 1 & 7 \\
\hline & & sore & 1100 & 948 & 2 & 6 \\
\hline
\end{tabular}

(Sumber:Data Sampling, 2020)

Pada Tabel 4, jumlah kendaraan tertinggi adalah di titik 2 (pengukuran pagi, siang, maupun sore hari). Jenis dan jumlah kendaraan terbanyak didominasi oleh kendaraan penumpang seperti mobil penumpang dan sepeda motor, hal ini karena banyaknya aktivitas masyarakat di pusat Kota Medan seperti perkantoran, sarana kesehatan, maupun sarana hiburan seperti mall.

Menurut (Samosir 2017), volume kendaraan merupakan faktor penting dalam peningkatan atau penurunan konsentrasi polutan. Dimana semakin tinggi volume kendaraan pada jam pengukuran maka konsentrasi polutan juga akan semakin tinggi. Sebaliknya, jika estimasi volume kendaraan rendah maka konsentrasi polutan juga akan rendah.

\section{Laju Emisi CO}

Berdasarkan hasil traffic counting (jenis dan jumlah kendaraan) maka langkah selanjutnya adalah menghitung beban emsi $\mathrm{CO}$ dengan menggunakan rumus pada persamaan (1), maka didapatkan beban emisi CO di wilayah studi terlihat pada Tabel 5.

Tabel 5. Total Beban Emisi CO di Sekitar Kawasan Balai Kota

\begin{tabular}{|c|c|c|c|c|}
\hline No & Nama Lokasi & Waktu & $\begin{array}{l}\text { Total Beban } \\
\text { Emisi }\end{array}$ & Satuan \\
\hline \multirow{3}{*}{1.} & \multirow{3}{*}{ Bank Muamalat } & Pagi & 46,86 & $\mathrm{~g} / \mathrm{m} / \mathrm{jam}$ \\
\hline & & Siang & 50,93 & $\mathrm{~g} / \mathrm{m} / \mathrm{jam}$ \\
\hline & & Sore & 58,05 & $\mathrm{~g} / \mathrm{m} / \mathrm{jam}$ \\
\hline \multirow{3}{*}{2.} & \multirow{3}{*}{ Hotel Grand Inna } & Pagi & 116,98 & $\mathrm{~g} / \mathrm{m} / \mathrm{jam}$ \\
\hline & & Siang & 103,33 & $\mathrm{~g} / \mathrm{m} / \mathrm{jam}$ \\
\hline & & Sore & 130,49 & $\mathrm{~g} / \mathrm{m} / \mathrm{jam}$ \\
\hline
\end{tabular}




\begin{tabular}{|c|c|c|c|c|}
\hline No & Nama Lokasi & Waktu & $\begin{array}{l}\text { Total Beban } \\
\text { Emisi }\end{array}$ & Satuan \\
\hline \multirow{3}{*}{3.} & \multirow{3}{*}{ Grapari Telkomsel } & Pagi & 67,47 & $\mathrm{~g} / \mathrm{m} / \mathrm{jam}$ \\
\hline & & Siang & 54,48 & $\mathrm{~g} / \mathrm{m} / \mathrm{jam}$ \\
\hline & & Sore & 62,14 & $\mathrm{~g} / \mathrm{m} / \mathrm{jam}$ \\
\hline \multirow{3}{*}{4.} & \multirow{3}{*}{ Deli Park } & Pagi & 72,50 & $\mathrm{~g} / \mathrm{m} / \mathrm{jam}$ \\
\hline & & Siang & 61,96 & $\mathrm{~g} / \mathrm{m} / \mathrm{jam}$ \\
\hline & & Sore & 81,42 & $\mathrm{~g} / \mathrm{m} / \mathrm{jam}$ \\
\hline \multirow{3}{*}{5.} & \multirow{3}{*}{$\begin{array}{l}\text { Mini Market YES } \\
248\end{array}$} & Pagi & 7,46 & $\mathrm{~g} / \mathrm{m} / \mathrm{jam}$ \\
\hline & & Siang & 7,76 & $\mathrm{~g} / \mathrm{m} / \mathrm{jam}$ \\
\hline & & Sore & 6,57 & $\mathrm{~g} / \mathrm{m} / \mathrm{jam}$ \\
\hline \multirow{3}{*}{6.} & \multirow{3}{*}{ Bank Mandiri } & Pagi & 4,01 & $\mathrm{~g} / \mathrm{m} / \mathrm{jam}$ \\
\hline & & Siang & 8,83 & $\mathrm{~g} / \mathrm{m} / \mathrm{jam}$ \\
\hline & & Sore & 7,51 & $\mathrm{~g} / \mathrm{m} / \mathrm{jam}$ \\
\hline
\end{tabular}

(Sumber: Hasil Perhitungan, 2020)

Laju emisi tertinggi berada di titik 2 (Hotel Grand Inna), hal ini dikarenakan pada lokasi ini berada dekat dengan simpang 3 yang terdapat pemberhentian lampu lalu lintas, sehingga selalu terdapat penumpukan kendaraan bermotor. Lokasi ini merupakan jalan dengan volume lalu lintas yang sangat tinggi, juga terdapat keramaian karena salah satu pintu masuk utama ke Kawasan Merdeka Walk.

\section{Kondisi Meteorologi di Kawasan Balai Kota, Medan}

Pendispersian polutan di udara ambien dipengaruhi oleh faktor meteorologi diantaranya adalah kecepatan dan arah angin serta suhu. Data arah angin diperoleh dari Balai Besar BMKG Wilayah 1 Medan (Stasiun Klimatologi Sampali Medan), sedangkan data kecepatan angin dan suhu udara diperoleh pada saat sampling di lapangan. Data kecepatan dan arah angin di Kawasan Balai Kota Medan dapat dilihat pada Tabel 6.

Tabel 6. Kecepatan dan Arah Angin di Kawasan Balai Kota Medan

\begin{tabular}{|c|c|c|c|c|}
\hline No Titik & Lokasi & Waktu & $\begin{array}{l}\text { Kecepatan } \\
\text { Angin } \\
(\mathrm{m} / \mathrm{s}) \\
\end{array}$ & $\begin{array}{l}\text { Arah } \\
\text { Angin }\left({ }^{0}\right)^{*}\end{array}$ \\
\hline \multirow{3}{*}{1.} & \multirow{3}{*}{ Depan Bank Muamalat } & Pagi & 2,6 & $140^{\circ}$ \\
\hline & & Siang & 2,3 & $140^{\circ}$ \\
\hline & & Sore & 2,3 & $140^{\circ}$ \\
\hline \multirow{3}{*}{2.} & \multirow{3}{*}{ Depan Hotel Grand Inna } & Pagi & 2.7 & $140^{\circ}$ \\
\hline & & Siang & 2.8 & $140^{\circ}$ \\
\hline & & Sore & 2.67 & $140^{\circ}$ \\
\hline \multirow{3}{*}{3.} & \multirow{3}{*}{ Depan Grapari Telkomsel } & Pagi & 3.21 & $280^{\circ}$ \\
\hline & & Siang & 3,80 & $280^{\circ}$ \\
\hline & & Sore & 2,96 & $280^{\circ}$ \\
\hline \multirow{3}{*}{4.} & \multirow{3}{*}{ Depan Delipark Medan } & Pagi & 2,92 & $280^{\circ}$ \\
\hline & & Siang & 4,34 & $280^{\circ}$ \\
\hline & & Sore & 2,64 & $280^{\circ}$ \\
\hline \multirow{3}{*}{5.} & \multirow{3}{*}{ Depan ISPU Kota Medan } & Pagi & 3,16 & $210^{\circ}$ \\
\hline & & Siang & 3,20 & $210^{\circ}$ \\
\hline & & Sore & 2,52 & $210^{\circ}$ \\
\hline \multirow{3}{*}{6.} & \multirow{3}{*}{ Depan Bank Mandiri } & Pagi & 2,86 & $210^{\circ}$ \\
\hline & & Siang & 3,25 & $210^{\circ}$ \\
\hline & & Sore & 4,97 & $210^{\circ}$ \\
\hline
\end{tabular}

(Sumber: Data Sampling, 2020 dan *BMKG, 2020) 
Berdasarkan Tabel 6, kecepatan angin di sekitar Kawasan Balai Kota Medan berada dikisaran 2,3 m/s sampai dengan $4.97 \mathrm{~m} / \mathrm{s}$.

Berdasarkan hasil pengujian yang dilakukan oleh (Ginting 2017) ditemukan adanya hubungan yang kuat antara pengaruh kecepatan angin terhadap konsentrasi CO yang dihasilkan. Pengaruh kecepatan angin yang dihasilkan adalah 54,9\%, selebihnya dapat dipengaruhi oleh factor lain. Semakin tinggi kecepatan angin, semakin rendah konsentrasi CO yang dihasilkan.

Tabel 7. Data Suhu Udara di Lokasi Penelitian

\begin{tabular}{|c|c|c|c|c|}
\hline No Titik & Nama Titik & Waktu & $\begin{array}{l}\text { Suhu } \\
\left({ }^{\circ} \mathrm{C}\right)\end{array}$ & Rata-Rata \\
\hline \multirow{3}{*}{1.} & \multirow{3}{*}{ Bank Muamalat } & Pagi & & 27,9 \\
\hline & & Siang & & 31,0 \\
\hline & & Sore & & 35,0 \\
\hline \multirow{3}{*}{2.} & \multirow{3}{*}{ Hotel Grand Inna } & Pagi & & 29,4 \\
\hline & & Siang & & 33,3 \\
\hline & & Sore & & 31,9 \\
\hline \multirow{3}{*}{3.} & \multirow{3}{*}{ Grapari Telkomsel } & Pagi & & 28,3 \\
\hline & & Siang & & 28,8 \\
\hline & & Sore & & 30,6 \\
\hline \multirow{3}{*}{4.} & \multirow{3}{*}{ Deli Park } & Pagi & & 28,6 \\
\hline & & Siang & & 30,6 \\
\hline & & Sore & & 29,2 \\
\hline \multirow{3}{*}{5.} & \multirow{3}{*}{ Mini Market YES 248} & Pagi & & 28,0 \\
\hline & & Siang & & 32,9 \\
\hline & & Sore & & 31,9 \\
\hline \multirow{3}{*}{6.} & \multirow{3}{*}{ Bank Mandiri } & Pagi & & 30,8 \\
\hline & & Siang & & 32,6 \\
\hline & & Sore & & 28,1 \\
\hline
\end{tabular}

(Sumber: Data Sampling, 2020)

Konsentrasi CO juga dapat dipengaruhi oleh faktor meteorologis, termasuk suhu. Sejalan dengan penelitian yang dilakukan oleh (Ramayana and Istirokhatun 2014), menunjukkan bahwa temperatur pada saat peninjauan di tiga ruas jalan (Jalan Karangrejo Raya, Jalan Sukun Raya dan Jalan Ngesrep Timur V) berbanding terbalik dengan konsentrasi CO, kenaikan temperatur diikuti dengan penurunan jumlah $\mathrm{CO}$.

\section{Konsentrasi CO dengan Menggunakan Model Meti-Lis}

Pemodelan dispersi polutan CO di udara ambien menggunakan aplikasi Meti-Lis dengan input data laju emisi, volume kendaraan, kecepatan angin, arah angin, suhu, koordinat jalan, lebar jalan, dan koordinat reseptor. Keseluruhan hasil analisis perhitungan konsentrasi CO di Kawasan Balai Kota Medan dengan menggunakan Model Meti-Lis disajikan pada Tabel 6 berikut.

Tabel 8. Konsentrasi CO dengan Menggunakan Model Meti-Lis

\begin{tabular}{llll}
\hline No Titik & Lokasi Titik Pengamatan & Waktu Pengukuran & $\begin{array}{l}\text { Konsentrasi CO } \\
\left(\boldsymbol{\mu g} / \mathbf{m}^{\mathbf{3}}\right)\end{array}$ \\
\hline \multirow{2}{*}{1.} & \multirow{3}{*}{ Bank Muamalat } & Pagi & 468,03 \\
& & Siang & 816,13 \\
\hline \multirow{2}{*}{2.} & Sore & 930,22 \\
\hline
\end{tabular}




\begin{tabular}{|c|c|c|c|}
\hline No Titik & Lokasi Titik Pengamatan & Waktu Pengukuran & $\begin{array}{l}\text { Konsentrasi CO } \\
\left(\mu \mathrm{g} / \mathrm{m}^{3}\right)\end{array}$ \\
\hline & & Sore & $2.452,12$ \\
\hline \multirow{3}{*}{3.} & \multirow{3}{*}{ Deli Park } & Pagi & 798,89 \\
\hline & & Siang & 543,22 \\
\hline & & Sore & 811,89 \\
\hline \multirow{3}{*}{4.} & \multirow{3}{*}{ Grapari Telkomsel } & Pagi & 517,41 \\
\hline & & Siang & 354,47 \\
\hline & & Sore & 648,12 \\
\hline \multirow{3}{*}{5.} & \multirow{3}{*}{ Mini Market YES 248} & Pagi & 111,23 \\
\hline & & Siang & 112,09 \\
\hline & & Sore & 121,47 \\
\hline \multirow{3}{*}{6.} & \multirow{3}{*}{ Bank Mandiri } & Pagi & 8,44 \\
\hline & & Siang & 16,27 \\
\hline & & Sore & 8,68 \\
\hline
\end{tabular}

(Sumber : Hasil Analisa, 2020)

Berdasarkan Tabel 8, hasil konsentrasi CO di Kawasan Balai Kota Medan dengan menggunakan Model Meti-Lis masih memenuhi ambang batas udara ambien yang berlaku di Indonesia yaitu PPRI. No. 22 Tahun 2021(Indonesia 2021) dimana baku mutu untuk parameter CO untuk 1 (satu) jam pengukuran sebesar $10.000 \mu \mathrm{g} / \mathrm{m} 3$. Dapat dilihat konsentrasi CO tertinggi di Kawasan Balai Kota Medan berada di Titik 2 tepatnya disore hari yaitu sebesar $2.452,12 \mu \mathrm{g} / \mathrm{m} 3$. Titik ini merupakan konvergensi dimana terdapat rambu-rambu lalu lintas, membuat kendaraan bermotor berhenti akibat lampu merah sehingga terjadi antrean kendaraan bermotor. Pada saat kendaraan dalam posisi idle, maka akan terjadi pelepasan gas termasuk gas $\mathrm{CO}$, hal ini terjadi karena pengapian yang terfragmentasi dan suhu yang umumnya rendah karena putaran mesin motor yang rendah, sehingga konsumsi bahan bakar akan di atas kecepatan ideal. Model Meti-Lis memiliki hasil output berupa peta isopleth sebaran nilai konsentrasi pada suatu grid (wilayah yang telah ditentukan). Berikut akan ditunjukkan beberapa peta isopleth dari masing-masing titik dengan nilai konsentrasi $\mathrm{CO}$ tertinggi.

Menurut penelitian (Rangga 2014), pemodelan roadside dari Meti-lis di 3 (tiga) lokasi di Kota Pontianak diperoleh konsentrasi beriksar 4.088,34 $\mu \mathrm{g} / \mathrm{Nm}^{3}-4.146 \mu \mathrm{g} / \mathrm{Nm}^{3}$ dengan konsentrasi tertinggi berada di Jalan Sutan Syahrir, Pontianak. Kondisi ini terjadi karena jumlah kendaraan yang melintasi jalan Sutan Syahrir lebih banyak dibandingkan 2 (dua) lokasi lainnya. Sejalan dengan penelitian (Winardi 2015) dengan menggunakan Model Meti-Lis, didapatkan perbedaan konsentrasi dari 6 wilayah kecamatan di Kota Pontianak yang disebabkan oleh kepadatan kendaraan yang berbeda disetiap wilayah penelitian. Demikian juga penelitian yang dilakukan (Dong 2020), dengan menggunakan model yang sama di beberapa jalan di Kawasan Cau Giay, Hanoi untuk waktu penelitian pada musim panas dan musim dingin didapatkan konsentrasi polutan berbeda yang dipengaruhi oleh banyaknya aktivitas kendaraan, dimana rute yang melewati area terminal bus My Dinh yang merupakan jalan utama yang menghubungkan ke pusat kota, sehingga banyak mobil penumpang, bus, dan truk-truk besar melintas di jalur tersebut setiap hari. 


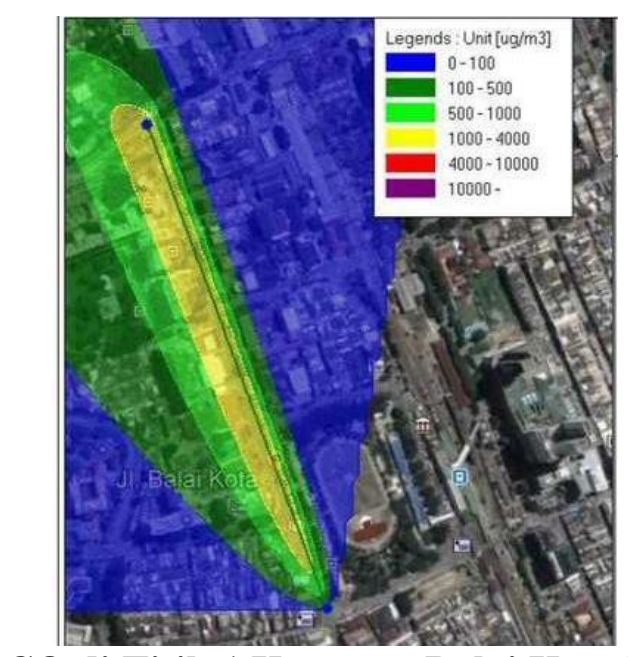

Gambar 1. Pola Sebaran CO di Titik 1 Kawasan Balai Kota Menggunakan Model MetiLis di Sore Hari

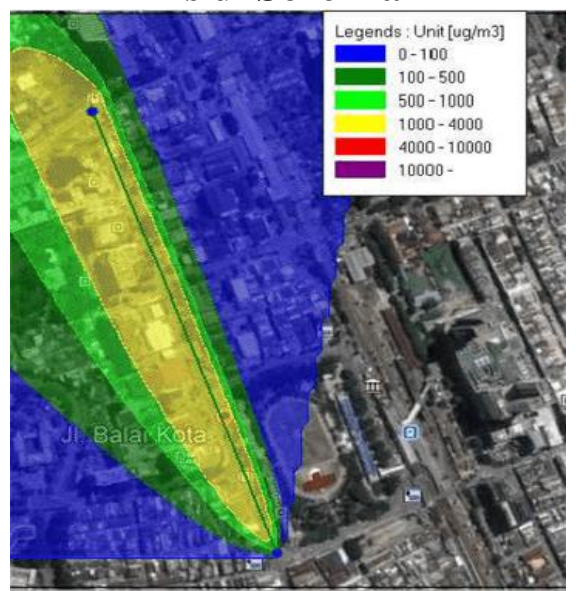

Gambar 2. Pola Sebaran CO di Titik 2 Kawasan Balai Kota Menggunakan Model MetiLis di Sore Hari

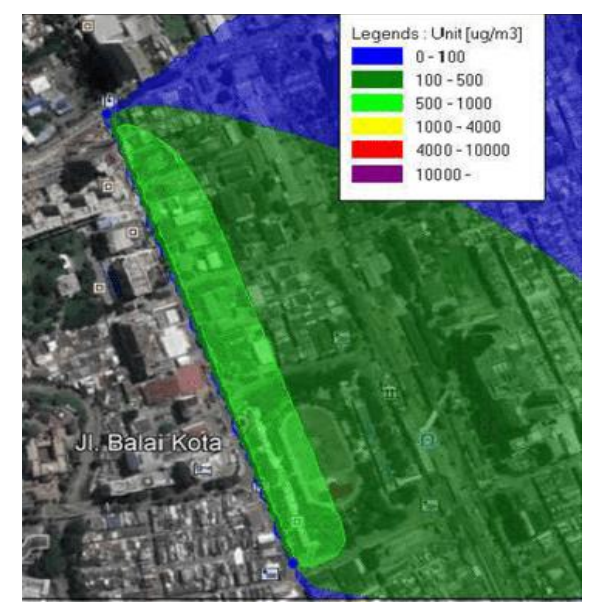

Gambar 3. Pola Sebaran CO di Titik 3 Kawasan Balai Kota Menggunakan Model MetiLis di Sore Hari 


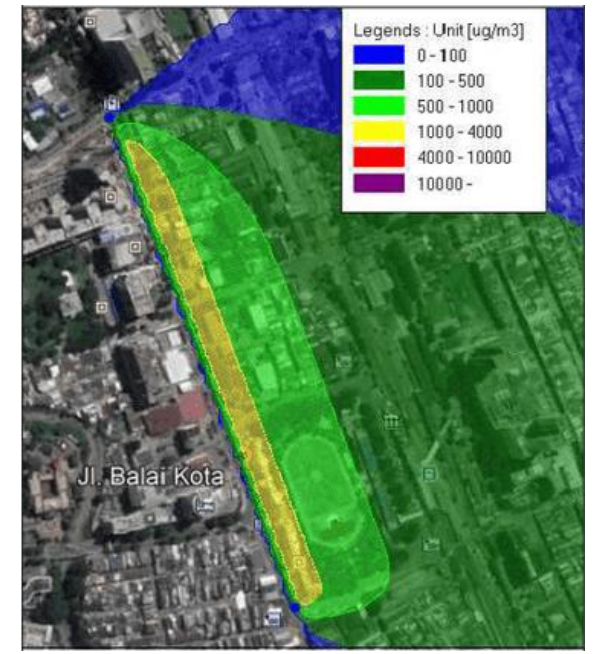

Gambar 4. Pola Sebaran CO di Titik 4 Kawasan Balai Kota Menggunakan Model MetiLis di Sore Hari

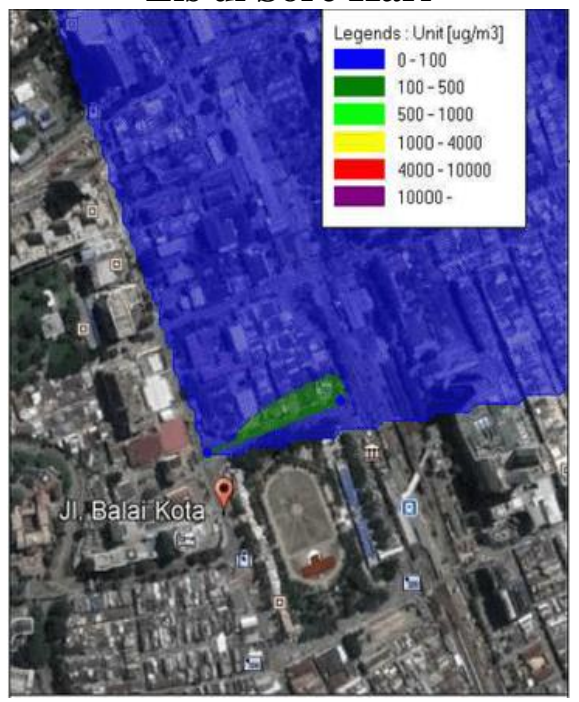

Gambar 5. Pola Sebaran CO di Titik 5 Kawasan Balai Kota Menggunakan Model MetiLis di Sore Hari

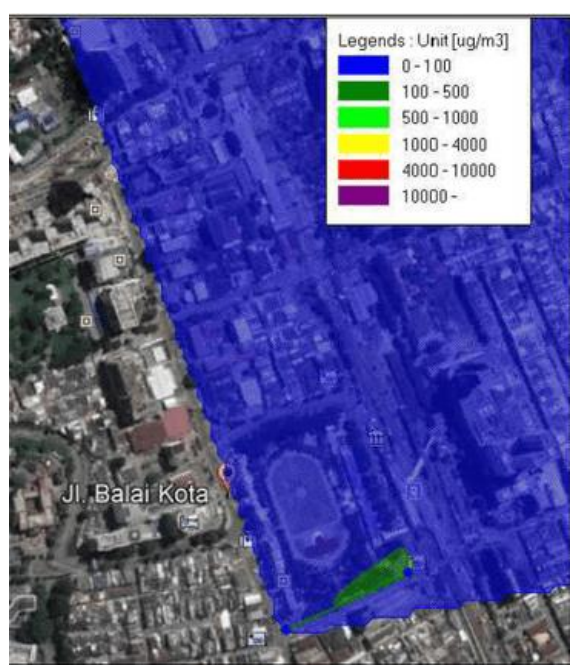

Gambar 6. Pola Sebaran CO di Titik 6 Kawasan Balai Kota Menggunakan Model MetiLis di Siang Hari 
Berdasarkan Gambar 1 dan Gambar 2, arah sebaran polutan dominan kearah barat laut. Untuk Gambar 3 dan Gambar 4 lebih dominan ke arah tenggara. Sedangkan Gambar 5 dan Gambar 6, sebaran polutan CO dominan ke arah timur laut. Arah sebaran polutan CO dari keselurahan titik berbeda dengan hasil visualisasi arah angin yang dihasilkan oleh windrose, hal ini disebabkan karena arah angin yang digunakan ke Model Meti-Lis merupakan arah angin pada saat sampling bukan arah angin dominan.

\section{Konsentrasi Karbon monoksida (CO) Pengukuran Langsung di Kawasan Balai Kota}

Pengukuran konsentrasi $\mathrm{CO}$ di Kawasan Balai Kota dilakukan dengan menggunakan alat ukur CO Digital Wohler CM 220. Titik sampling berada di tepi jalan (roadside) dengan lokasi dan konsentrasi CO seperti ditunjukkan pada Gambar 7.

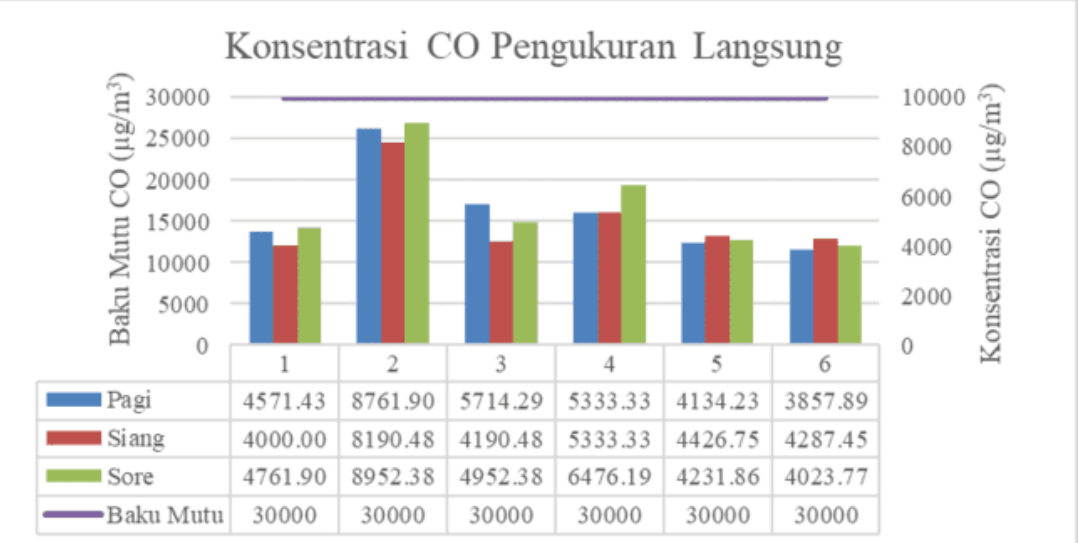

\section{Gambar 7. Konsentrasi CO Udara Ambien dari Pengukuran Langsung}

Berdasarkan Gambar 7, hasil pengukuran roadside konsentrasi CO di Kawasan Balai Kota Medan masih memenuhi ambang batas udara ambien yang berlaku yaitu PPRI. No. 22 Tahun 2021 (dibawah $10.000 \mu \mathrm{g} / \mathrm{m}^{3}$ ). Konsentrasi CO tertinggi di Kawasan Balai Kota Medan yaitu pengukuran pada titik 2 sore hari sebesar $8.952 .38 \mu \mathrm{g} / \mathrm{m}^{3}$ dan Konsentrasi CO terendah di Kawasan Balai Kota Medan yaitu berada pada titik 1 (satu) pengukuran siang hari sebesar $4.000 \mu \mathrm{g} / \mathrm{m}^{3}$.

Beberapa factor meteorologi yang mempengaruhi pemodelan adalah kecepatan dan arah angin, kelembaban udara, suhu udara, curah hujan, serta radiasi matahari dan juga jumlah kendaraan yang berbeda pada saat sampling mengakibatkan konsentrasi yang diperoleh tidak stabil (Sinaga and Handayani 2013).

\section{Uji Validasi}

Validasi dari hasil model dengan konsentrasi CO pengukuran langsung disajikan pada Tabel 9. Hasil analisa CO pada model dapat disetujui apabila hasil validasi sesuai dengan kriteria yang telah ditentukan merujuk pada penelitian (Vega Paramitadevi 2014).

\section{Tabel 9. Validasi CO Hasil Analisa Model Meti-Lis}

\begin{tabular}{cl}
\hline Validasi & Nilai \\
\hline $\mathrm{D}$ & 0,998 \\
\hline $\mathrm{FB}$ & $-0,085$ \\
\hline $\mathrm{R}$ & 0,917 \\
\hline $\mathrm{Fa}_{2}$ & 0,133 \\
\hline (Sumber: Hasil Perhitungan, 2020) &
\end{tabular}

Berdasarkan Tabel 9, nilai index of agreement (d) yang diperoleh sebesar 0,998 atau dapat diartikan $99 \%$ data yang diperoleh valid dan $1 \%$ error. Nilai d yang mendekati 1 
menunjukkan kesesuian yang tinggi antara hasil model dengan konsentrasi pengamatan langsung.

Fractional Bias (FB) yang dipeoleh sebesar -0,085. Kriteria Fractional Bias $(\mathrm{Fb})$ yaitu berada diantara -2 sampai dengan 2. Nilai FB mendekati -2 menunjukkan kondisi antara konsentrasi model dibawah nilai konsentrasi pengukuran langsung. Sedangkan nilai Fa2 yang diperoleh sebesar 0,133. Nilai ini tidak masuk dalam kriteria yang ditentukan. Kondisi antara model dan pengukuran dapat diterima apabila nilai $\mathrm{Fa} 2$ berada diantara 0,5 sampai dengan 2 .

Hasil dari analisa validasi dari 4 (empat) jenis validasi dimana 3 jenis validasi tersebut memenuhi kriteria persyaratan, berdasarkan analisa tersebut model Meti-Lis sesuai untuk diterapkan di Kawasan Balai Kota Medan. Hal ini terjadi karena dalam perhitungan model Meti-Lis sumber emisi yang berasal dari kendaraan bermotor memprediksikan nilai konsentrasi CO berdasarkan kepadatan lalu lintas (banyaknya kendaraan yang melewati) yang sejalan dengan nilai konsentrasi CO pada pengukuran langsung di lokasi pengamatan.

Selain itu, Model Meti-Lis bersifat steady state dimana parameter laju emisi dan meteorologi sama setiap saat, dalam asumsi pemodelan Model Meti-Lis mempunyai asumsi bahwa sifatnya stabil sedangkan dalam pengukuran langsung sifatnya mengikuti fluktuasi volume kendaraan bermotor dan faktor meteorologi. Meti-Lis merupakan model yang dirancang untuk kawasan yang sumbernya dapat diperhitungkan dalam model adalah sumber titik atau sumber garis, serta kombinasi kedua sumber emisi. Pada penelitian ini yang dijadikan input dalam menjalankan model ini hanya berasal dari sumber garis sehingga berpengaruh terhadap konsentrasi dari pemodelan.

\section{SIMPULAN}

Berdasarkan hasil pengukuran kosentrasi CO udara ambien dan Model Meti-Lis di Kawasan Balai Kota Medan, konsentrasi CO tertinggi dari 6 titik yang diamati terdapat di titik 2 yaitu di depan Hotel Grand Inna dan konsentrasi CO terendah terdapat di titik 6 yaitu di depan Bank Mandiri.

Berdasarkan hasil uji validasi dengan Korelasi Pearson $(R)$, Wilmott's Index of Agreement (d), Factor of 2 (Fa2 $\neg)$,dan Friction Bias (FB), validasi hasil Model Meti-Lis terhadap nilai konsentrasi $\mathrm{CO}$ pada pengukuran langsung memenuhi persyaratan kriteria validasi, sehingga Model Meti-Lis sesuai untuk diterapkan di Kawasan Balai Kota Medan.

\section{DAFTAR PUSTAKA}

Aslim, Muhammad Arief Fitrah Istiyanto, Nasrul Ihsan, and Ahmad Yani. 2019. "PEMODELAN SEBARAN POLUTAN UDARA AKIBAT AKTIVITAS PLTD TELLO KOTA MAKASSAR MENGGUNAKAN MODEL DISPERSI GAUSS." Jurnal Sains dan Pendidikan Fisika (JSPF) 15(1): 36-44.

Badan Pusat Statistik Kota Medan. 2019. Kota Medan Dalam Angka 2019. Medan: BPS.

Dong, Nguyen Phuong. 2020. "MODELING AIR POLLUTION FROM VEHICLE EXHAUST AND APPLICATION TO STUDY AIR QUALITY FOR CAU GIAY DISTRICT , HANOI.” 22(2): 90-96.

Ginting, Ivana Ameta Putri. 2017. “Analisis Pengaruh Jumlah Kendaraan Kelembaban , Dan Kecepatan Angin ) Terhadap Konsentrasi Karbon Monoksida ( CO ) Di Udara Ambien Roadside ( Studi Kasus : Pintu Tol Amplas Dan Pintu Tol Tanjung Morawa ).” Tugas Akhir Teknik Lingkungan USU: 1-143. 
Ilmiawan, Dwiki Fahmi. 2019. "Proyeksi Penurunan Beban Emisi Co Sumber Transportasi Di Beberapa Ruas Jalan Kota Medan Dengan Skenario Sistem Bus Rapid Transit (Brt)." Tugas Akhir Teknik Lingkungan USU.

Indonesia, Republik. 2021. "Peraturan Pemerintah Nomor 22 Tahun 2021 Tentang Pedoman Perlindungan Dan Pengelolaan Lingkungan Hidup." Sekretariat Negara Republik Indonesia 1(078487A): 483. http://www.jdih.setjen.kemendagri.go.id/.

Kementrian Lingkungan Hidup. 2010. "Peraturan Menteri Negara Lingkungan Hidup Nomor 12 Tahun 2010 Tentang Pelaksanaan Pengendalian Pencemaran Udara Di Daerah." Pelaksaan Pengedalian Pencemaran Udara Di Daerah Menteri Negara Lingkungan Hidup: 1-199. www.menlhk.go.id.

Ramayana, Kiki, and Titik Istirokhatun. 2014. "PENGARUH JUMLAH KENDARAAN DAN FAKTOR METEOROLOGIS ( SUHU , KELEMBABAN , KECEPATAN ANGIN ) TERHADAP PENINGKATAN KONSENTRASI GAS PENCEMAR CO ( Karbon Monoksida ) PADA PERSIMPANGAN JALAN KOTA SEMARANG ( STUDI KASUS JALAN KARANGREJO RAYA , SUKUN RAYA , Dan NG." Teknik Lingkungan UNDIP.

Rangga, Boy. 2014. "Analisis Dispersi Gas Karbon Monoksida (CO).” Jurnal Mahasiswa Teknik Lingkungan UNTAN 2, No. 1: 1-11.

Samosir, Ridwan. 2017. "ANALISIS KONSENTRASI SO 2 DAN CO MENGGUNAKAN MODEL GAUSSIAN LINE SOURCE DI UDARA AMBIEN ( Studi Kasus : Pintu Tol Tanjung Morawa Dan Pintu Tol Amplas )." Tugas Akhir Teknik Lingkungan USU.

Sinaga, Sartikasmawaty, and Dwi Siwi Handayani. 2013. "Pengaruh Jumlah Kendaraan Dan Faktor Metorologis Terhadap Konsentrasi Karbon Monooksida (CO) Di Jalan Pandanaran Kawasansimpang Lima, Kota Semarang.” Teknik Lingkungan UNDIP: 1-8.

Suryati, Isra' dan Hafizhul Khair. 2016. “Analisis Isophlet Konsentrasi Dan Estimasi Potensi Penurunan Karbon Monoksida Di Kota Medan.” Dampak Teknik Lingkungan UNAND 13(2): $1-9$.

Vega Paramitadevi, Yudith. 2014. "Simulasi Dan Validasi Model Dispersi Karbon Monoksida (CO) Di Sekitar Pintu Tol Baranangsiang Bogor.” Tesis Pasca Sarjana Ilmu Lingkungan $I P B$.

Winardi. 2015. "DISPERSI GAS KARBON MONOKSIDA (CO) DARI SUMBER TRANSPORTASI DI KOTA PONTIANAK." Prosiding SEMIRATA 2015 bidang MIPA BKS-PTN Barat: 737-46. 